\title{
Carnobacterium inhibens sp. nov., isolated from the intestine of Atlantic salmon (Salmo salar)
}

\author{
Anna Jöborn, ${ }^{1}$ Matthias Dorsch, ${ }^{2}$ J. Christer Olsson, ${ }^{1}$ Allan Westerdahl ${ }^{1}$ \\ and Staffan Kjelleberg ${ }^{2}$
}
1 Department of General and Marine Microbiology, University of Göteborg, Medicinaregatan 9C, 413 90 Göteborg, Sweden
2 School of Microbiology and Immunology, University of New South Wales, Sydney, NSW 2052, Australia

\author{
Author for correspondence: Anna Jöborn. Tel: +46 31 7732599. Fax: +46 317732599 \\ e-mail: anna.joborn@o.lst.se
}

\begin{abstract}
Strain K1', isolated from the gastrointestinal tract of Atlantic salmon (Salmo salar), has the capacity to inhibit the growth of the fish pathogens Vibrio anguillarum and Aeromonas salmonicida. Strain $\mathrm{K1}^{\top}$ is a motile Gram-positive psychrophilic rod that lacks both catalase and oxidase, which does not grow on acetate containing media, but grows at pH 9 and in TSB with up to $6 \%$ sodium chloride content. Strain $\mathrm{K1}^{\top}$ is facultatively anaerobic and tryptone as a sole source of nutrient promotes growth. The most abundant cellular fatty acid of strain $\mathrm{K1}^{\top}$ is oleic acid (18:1cis9). Based on 165 rDNA sequence comparisons, it is suggested that strain $\mathrm{K1}^{\top}$ is phylogenetically closely related to $C$. alterfunditum. However, the unique phenotypic attributes of strain $\mathrm{K1}{ }^{\mathrm{T}}$ suggest that it represents a new species. The name Carnobacterium inhibens is proposed, for which the type strain is $\mathrm{K1}^{\top}$ ( = CCUG $31728^{\top}$ ).
\end{abstract}

Keywords: Carnobacterium inhibens, Vibrio anguillarum, Aeromonas salmonicida, intestinal microbiota, Atlantic salmon

\section{INTRODUCTION}

The gastrointestinal tract of fish is a nutrient rich habitat suitable for microbial growth. The information on composition and abundance of bacteria in the gastrointestinal tract of fish is steadily increasing. However, there are few examples where a specific function can be assigned to a certain bacterial group or species. It is recognized that some isolated bacteria from the gastrointestinal tract of fish have the ability to inhibit growth of bacterial fish pathogens in vitro (Schröder et al., 1980; Strøm, 1988; Westerdahl et al., 1991). It can be hypothesized that these inhibitory bacteria may be able to prevent the colonization and proliferation of bacterial pathogens that invade the gastrointestinal tract of fish. A group of Lactobacillus -like bacteria were isolated during a screening procedure (Jöborn et al., 1997) designed to select intestinal bacteria in Atlantic salmon (Salmo salar) with capacity to prevent the growth of the two common bacterial fish pathogens Vibrio anguillarum and Aeromonas salmonicida. There exist a number of reports in the literature on the presence of atypical lactic acid bacteria in the

The EMBL accession number for the 165 rDNA sequence of $C$. inhibens strain $\mathrm{K} 1^{\mathrm{T}}$ is $\mathrm{Z73313.}$ intestine of fish (Baya et al., 1991; Evelyn \& McDermott, 1961; Humphrey et al., 1987; Knøchel, 1981; Kvasnikov et al., 1977; Ringø, 1993; Ross \& Toth, 1974; Schröder et al., 1980). However, the phylogeny of this group of bacteria needs to be investigated in more detail in order to arrive at a better understanding of their appropriate taxonomic assignments as well as their role in the gastrointestinal tract of fish.

In this study, the phylogeny of one of the Lactobacilluslike bacteria isolated from Atlantic salmon, designated strain $\mathrm{K} 1^{\mathrm{T}}$, with marked growth inhibitory effects in vitro against Vibrio anguillarum and Aeromonas salmonicida, is evaluated. The inhibitory activity and colonization potential of strain $\mathrm{K} 1^{\mathrm{T}}$ have previously been investigated (Jöborn et al., 1997). In this paper, strain $\mathrm{K}^{\mathrm{T}}$ is analysed by $16 \mathrm{~S}$ rDNA sequence comparison and characterized by a range of biochemical and physiological tests.

\section{METHODS}

Media, diluent and culture conditions. The media and diluent used were: tryptic soy broth (TSB; Difco) and TSBS (TSB supplemented with $2 \% \mathrm{NaCl}$ ); TSA (TSB $+15 \%$ agar) and TSAS (TSA supplemented with $2 \% \mathrm{NaCl}$ ); TSAS soft agar 
(TSBS + 5\% agar); marine agar (MA; Difco); nutrient agar (NA; Difco); brain heart infusion broth (BHI; Difco); Lactobacilli MRS (Difco); Cholera medium (TCBS; Oxoid); tryptone broth (TB) and tryptone agar (TA, 4\% tryptone (Difco) $+15 \%$ agar); marine minimal medium (MMM; Östling et al., 1991); NSS (Mårdén et al., 1985); Horse-blood agar (HBA, i.e. TSA supplemented with $5 \%$ horse blood); Columbia agar with $5 \%$ horse blood (CAHB).

Bacteria. An atypical lactic acid bacteria, denoted strain $\mathrm{Kl}^{\mathrm{T}}$, was found during a screening of bacteria, from the intestine of Atlantic salmon (Salmo salar) (Jöborn et al., 1997), which excrete substances which inhibit the growth of Vibrio anguillarum and Aeromonas salmonicida. The following organisms (EMBL accession numbers are in parentheses) were included in the construction of a phylogenetic tree: Carnobacterium alterfunditum (L08623), Carnobacterium divergens (X54270), Carnobacterium funditum (S86170), Carnobacterium gallinarum (X54269), Carnobacterium mobile (X54271), Carnobacterium piscicola (X54268), Vagococcus fluvialis (X54258) and Vagococcus salmoninarum (X54272). Also in this study Carnobacterium alterfunditum (CCUG 34643), C. divergens (CCUG 30094), C. gallinarum (CCUG 30095), C. mobile (CCUG 30096), Vibrio anguillarum $\mathrm{HI} 11360$ and $A$. salmonicida ATCC 14174 were used to test growth inhibition.

Morphological and biochemical characterization of strain $\mathbf{K} \mathbf{1}^{\mathrm{T}}$. The following conventional methods were employed to characterize strain $\mathrm{Kl}^{\mathrm{T}}$ : visual inspection of colony morphology and pigmentation on TSBS plates; cell morphology and motility from TSBS cultures was examined by light microscopy ( $\times 1250$ magnification); Gram staining and staining of the flagella (Heimbrook et al., 1989) was performed on overnight cultures in TSBS; spore staining was performed on stationary-phase cultures with malachitegreen and viability test of a culture heated for 10 and $30 \mathrm{~min}$ at 65 and $100^{\circ} \mathrm{C}$; haemolysis was tested on $\mathrm{HBA}$; presence of catalase and oxidase was tested with cells cultivated on TSBS. Since some lactic acid bacteria produce a pseudocatalase when supplied with haemoglobin (Axelsson, 1993), cells were grown on HBA and subsequently tested for catalase activity.

The utilization of a number of carbon sources and activity of various enzymes were tested at the National Collection of Industrial and Marine Bacteria, limited, Great Britain (NCIMB) and the Culture Collection, University of Göteborg, Sweden (CCUG). The results were complemented with tests using the API rapid ID32 STREP (bioMérieux) and API 20 (API Systems).

Growth characterization of strain $\mathrm{K} 1^{\top}$. The growth of strain $\mathrm{K} 1^{\mathrm{T}}$ was monitored by optical density at $600 \mathrm{~nm}$ at $23^{\circ} \mathrm{C}$ in aerobic TSBS cultures and the $\mathrm{pH}$ change during growth was followed. Furthermore, the ability of strain $\mathrm{K} 1^{\mathrm{T}}$ to grow at $0,15,28,30$ and $37^{\circ} \mathrm{C}$ was examined on TSAS plates and in TSBS. The growth in TSBS at various $\mathrm{pH}$ was tested. The growth in TSB and TB supplemented with $\mathrm{NaCl}$ was monitored in the range of $0-10 \% \mathrm{NaCl}$. Acid production after growth on the marine oxidation-fermentation medium (MOF) (Leifson, 1963) was tested. The ability of strain K $1^{\mathrm{T}}$ to grow anaerobically at $23^{\circ} \mathrm{C}$ was tested using TSAS plates in an anaerobic box (Forma Scientific). Growth was also tested in MMM (glucose excluded) to which had been added sucrose, maltose, mannitol, trehalose, Casamino acids, peptone, tryptone and yeast extract at various concentrations and in various combinations. Growth on different solid media including NA, TSA, TSAS, BHI, MA, MMM, TCBS, MRS, HBA and TA was monitored.
Cellular fatty acid analysis. The cellular fatty acid composition was analysed by staff at the Culture Collection, University of Göteborg, Sweden (CCUG). The bacterium was grown on $\mathrm{CAHB}$ for $24 \mathrm{~h}$ at $30^{\circ} \mathrm{C}$. The cells were harvested, washed in distilled water, and saponified. The liberated cellular fatty acids were methylated and extracted. The resulting cellular fatty acid methyl esters were analysed by a system similar to the MIDI-system (MIDI) on a Hewlett Packard 5890 gas chromatograph with an auto sampler (HP 7673). The cellular fatty acid methyl esters were separated by GC using a HP-5 cross-linked 5\% $\mathrm{Ph} \mathrm{Me}(5 \%$ diphenyl- and $95 \%$ dimethyl-polysiloxane) silicone column $(25 \mathrm{~m} \times 0.2 \mathrm{~mm} \times 0.33 \mu \mathrm{m})$. The identification of peaks were done according to a Hewlett Packard standard.

Antimicrobial susceptibility. The antimicrobial susceptibility of strain $\mathrm{K}^{\mathrm{T}}$ was determined using antibiotic-impregnated filter discs (Oxoid). The filter discs were placed on the surface of TSAS plates, that previously had been seeded with strain $\mathrm{K} 1^{\mathrm{T}}$. The plates were incubated at $23^{\circ} \mathrm{C}$ for $48 \mathrm{~h}$ and thereafter examined for zones of no growth around the filter discs. The following antibiotics were tested at various concentrations: gentamicin $(30 \mu \mathrm{g})$, neomycin $(30 \mu \mathrm{g})$, erythromycin $(15 \mu \mathrm{g})$, rifampicin $(5 \mu \mathrm{g})$, tetracycline $(30 \mu \mathrm{g})$, ampicillin $(10 \mu \mathrm{g})$, kanamycin $(30 \mu \mathrm{g})$ and nalidixic acid $(30 \mu \mathrm{g})$.

Isolation of genomic DNA. Cells were grown on TSAS plates for 24 hours at $23^{\circ} \mathrm{C}$. Cells from one plate were overlaid with $5 \mathrm{ml} \mathrm{TE}$ buffer (Maniatis et al., 1982) and suspended in the buffer using a sterile glass spatula. The cell suspension was transferred into Eppendorph tubes and the DNA was isolated and purified as described previously (Rainey et al., 1992).

Amplification and sequencing of 16S rDNA. 16S rDNA was PCR-amplified as published previously (Dorsch \& Stackebrandt, 1992) and the products purified employing the Prep-A-Gene kit (Bio-Rad) according to the manufacturer's instructions. Purified PCR products were sequenced using a modified protocol for the Sequenase kit version 2.0 (USB) as published previously (Dorsch \& Stackebrandt, 1992). Sequencing products were separated on wedge-shaped gels ( $8 \%$ polyacrylamide, $8 \mathrm{M}$ urea) in Macrophore Systems (LKB-Pharmacia). Electrophoresis was performed for 2.5 and $6 \mathrm{~h}(2200 \mathrm{~V}$, constant voltage). Gels were washed in $10 \%$ acetic acid, $10 \%$ acetic acid $/ 10 \%$ methanol (20 min each) and dried at $80^{\circ} \mathrm{C}$ for $2 \mathrm{~h}$. X-ray films (Amersham) were exposed for 12-18 h. The generated sequence covered positions 11-1512 according to the Escherichia coli numbering system (Brosius et al., 1978).

Phylogenetic analysis based on 16S rDNA. The 16S rDNA sequence was subjected to 'Fast Analysis' against the GenBank database through ANGIS (Australian National Genomic Information Service) in order to determine the organisms exhibiting the highest $16 \mathrm{~S}$ rDNA sequence homologies. The following organisms (EMBL accesion numbers are in parentheses) were included in the construction of a phylogenetic tree to determine the phylogenetic position of the strain $\mathrm{K}^{\mathrm{T}}$ : C. alterfunditum (L08623), C. divergens (X54270), C. funditum (S86170), C. gallinarum (X54269), C. mobile (X54271), C. piscicola (X54268), Vagococcus fluvialis (X54258) and Vagococcus salmoninarum (X54272). A multiple sequence alignment was created using CLUSTAL W (version 1.5) and a phylogenetic tree constructed employing the neighbour-joining method of Saitou \& Nei (1987). Both programs were accessed through ANGIS. Sequence gaps were not included in the phylogenetic 
analysis. Due to partially incomplete sequences of the included reference organisms, the alignment covered positions $107-1471$ ( $E$. coll numbering system).

Growth inhibition by Carnobacterium species. The ability of the Carnobacterium species $C$. alterfunditum, $C$. divergens, $C$. gallinarum and $C$. mobile to inhibit the growth of Vibrio anguillarum and $A$. salmonicida, as well as strain $\mathrm{Kl}^{\mathrm{T}}$, was tested by a double agar technique (Westerdahl et al., 1991). The capability of strain $\mathrm{K}^{1 \mathrm{~T}}$ to inhibit the Carnobacterium species was also tested.

\section{RESULTS}

\section{Morphological, biochemical and growth characteristics of strain $\mathrm{K1}^{\top}$}

Strain $\mathrm{K} 1^{\mathrm{T}}$ is a Gram-positive, asporogenous rod. The colonies appear as buff-coloured and semi-translucent when grown under anaerobic conditions and whitish when grown aerobically. The colonies are $1-2 \mathrm{~mm}$ in diameter, raised, entire and circular. The morphology of strain $\mathrm{K} 1^{\mathrm{T}}$ in the exponential growth phase in TSBS is as $0.2 \times 0.3-0.7 \mu \mathrm{m}$ single or double rods (often occurring as $\mathrm{V}$-forms). In the stationary phase, the cells are $0.2 \times 0.5-1.2 \mu \mathrm{m}$ in pairs or as small chains of four cells. The cells are motile, with a single subpolar flagellum.

Strain $K 1^{\mathrm{T}}$ grows on all solid media tested except TCBS and MRS. It is fermentative in Leifson media (weak acid but no gas). Under anaerobic growth conditions the strain $\mathrm{K} 1^{\mathrm{T}}$ culture reaches a higher cell density than in aerated cultures. It grows at a temperature range between 0 and $30{ }^{\circ} \mathrm{C}$, at salinities between $0 \%$ and $6 \%$ and at a $\mathrm{pH}$ range of $5 \cdot 5-9 \cdot 0$. Strain $K 1^{\mathrm{T}}$ produces $\alpha$-haemolysis on HBA.

Strain $K 1^{\mathrm{T}}$ grows (and produces growth inhibitors) in $3 \%$ tryptone in MMM, as a sole source of nutrients. Casamino acids, yeast extract, pepton or various sugars, respectively, did not result in growth at the concentrations tested. However, various combinations of the nutrients did support growth. The generation time of the strain $\mathrm{K} 1^{\mathrm{T}}$ culture in TSBS at $23^{\circ} \mathrm{C}$ was $1.5 \pm 0.1 \mathrm{~h}$, as determined by optical density at $600 \mathrm{~nm}$. At the growth conditions employed in this study, the culture entered the stationary growth phase by a sharp transition at an optical density of approximately $0 \cdot 25$. When the growth had ceased the $\mathrm{pH}$ had decreased from 7.2 to 6.9 . Other phenotypic attributes of strain $\mathrm{K} 1^{\mathrm{T}}$ are presented together with literature data about C. funditum, C. alterfunditum and C. piscicola in Table 1. The analysis were performed by CCUG, NCIMB and by using API rapid ID32 STREP and API 20.

Strain $\mathrm{K} 1^{\mathrm{T}}$ did not produce acetoin and was not able to reduce nitrate to nitrite. Strain $\mathrm{K} 1^{\mathrm{T}}$ was found to hydrolyse hippurate. $\beta$-Glucosidase activity was demonstrated whereas no activity of the following enzymes could be detected: urease, $\beta$-galactosidase, $\beta$-glucuronidase, $\alpha$-galactosidase, arginine dihydrolase, alanylphenylalanyl-proline arylamidase, acid pyroglutamine arylamidase, $N$-acetyl- $\beta$-glucosaminidase.
The most abundant cellular fatty acids of strain $\mathrm{K} 1^{\mathrm{T}}$, according to the CCUG analysis, were found to be $16: 0(31 \cdot 1 \%), 16: 1(24 \cdot 2 \%)$ and $18: 1 \operatorname{cis} 9(23 \cdot 4 \%)$. Other fatty acids found were $18: 2$ cis 9,12 or $18: 0$ $(10.8 \%), 14: 0(5 \cdot 4 \%)$ and 18:0 (3.5\%). A comparison of the fatty acid composition of strain $\mathrm{Kl}^{\mathrm{T}}$ with various closely related Carnobacterium species is provided in Table 2.

Strain $\mathrm{K}^{\mathrm{T}}$ was sensitive to gentamicin $(30 \mu \mathrm{g})$, neomycin $(30 \mu \mathrm{g})$, erythromycin $(15 \mu \mathrm{g})$, rifampicin $(5 \mu \mathrm{g})$, tetracycline $(30 \mu \mathrm{g})$, ampicillin $(10 \mu \mathrm{g})$ and kanamycin $(30 \mu \mathrm{g})$, whereas it was resistant to nalidixic acid $(30 \mu \mathrm{g})$.

\section{Inhibitor production within the genus Carnobacterium}

The growth inhibition caused by a number of Carnobacterium species was investigated. C. alterfunditum, $C$. mobile, $C$. divergens and $C$. gallinarum did not inhibit Vibrio anguillarum HI11360 or Aeromonas salmonicida ATCC 14174, but they inhibited the growth of strain $\mathrm{K}^{\mathrm{T}}$. As previously shown (Jöborn et al., 1997), strain $\mathrm{K} 1^{\mathrm{T}}$ suppresses the growth of Vibrio anguillarum and $A$. salmonicida. However, strain $\mathrm{Kl}^{\mathrm{T}}$ did not inhibit the growth of the different Carnobacterium species tested.

\section{A phylogenetic tree based on 16S rDNA sequence comparisons}

An unrooted phylogenetic tree was constructed (Fig. 1). Strain $\mathrm{K} 1^{\mathrm{T}}$ showed close relatedness to $C$. alterfunditum. The phylogenetic groupings of $C$. gallinarum $/ C$. piscicola, $C$. mobile $/ C$. funditum and the isolated position of $C$. divergens are in accordance with previously published data (Franzmann et al., 1991; Wallbanks et al., 1990). Vagococcus salmoninarum and Vagococcus fluvialis were included as representatives of a remotely related genus. The significance of the branching points in the tree as determined by bootstrapping (Saitou \& Nei, 1987) was $73 \%$ (C. funditum $/ C$. mobile), $98.1 \%$ (C. alterfunditum $/$ strain $\left.\mathrm{K} 1^{\mathrm{T}}\right), 100 \%(C$. gallinarum $/ C$. piscicola $)$ and $100 \%$ (Vagococcus salmoninarum/Vagococcus fluvialis).

\section{DISCUSSION}

In the present study we examined the biochemical and genetic characteristics of a non-aciduric lactic acid bacterium isolated from the gastrointestinal tract of Atlantic salmon. It possesses the key attributes that confine the genus Carnobacterium (Collins et al., 1987). Strain $\mathrm{K} 1^{\mathrm{T}}$ is non spore-forming and cells occur as straight rods (singly, as pairs or as short chains). It is motile, Gram-positive, facultatively anaerobic and heterofermentative. It grows at $10^{\circ} \mathrm{C}$ but not at $35^{\circ} \mathrm{C}$. It does not grow in $8 \% \mathrm{NaCl}$ or in acetate containing media. It is catalase-negative and is not able to reduce nitrate to nitrite. The major fatty acids are of straight- 
Table 1. Physiological and biochemical charactersistics of $C$. inhibens sp. nov. (strain $\mathrm{K} 1^{\top}$ ) and C. funditum (DSM 5972 ${ }^{\top}$; Franzmann et al., 1991), C. alterfunditum (DSM 5970'; Franzmann et al., 1991), C. piscicola (DSM 20730'; Hiu et al., 1984)

All strains were negative for the following attributes: adonitol, rhamnose, dulcitol, inositol, sorbitol, starch, glycogen and nitrate reduction.

\begin{tabular}{|c|c|c|c|c|}
\hline Attribute & C. inhibens $\mathrm{K} 1^{\mathrm{T}}$ & $\begin{array}{l}\text { C. funditum } \\
\text { DSM 5972 }\end{array}$ & $\begin{array}{l}\text { C. alterfunditum } \\
\text { DSM 5970 }\end{array}$ & $\begin{array}{l}\text { C. piscicola } \\
\text { DSM 20730 }^{\mathrm{T}}\end{array}$ \\
\hline Motile & + & + & + & - \\
\hline Rods & + & + & + & + \\
\hline Spores & $-* \dagger$ & - & - & - \\
\hline Catalase & $-\ddagger$ & - & - & - \\
\hline Pseudo-catalase & $+\S$ & NT & NT & NT \\
\hline Oxidase & $-\ddagger$ & - & - & - \\
\hline Dextrin & - & NT & NT & - \\
\hline Glycerol & - & $\mathrm{w}$ & $\mathrm{w}$ & + \\
\hline Erythritol & - & NT & NT & - \\
\hline Arabinose & $+(\mathrm{L})$ & - & - & - \\
\hline Ribose & + & - & - & + \\
\hline Xylose & $-(\mathrm{D}$ and $\mathrm{L})$ & - & - & $-(\mathrm{D}$ and $\mathrm{L})$ \\
\hline Methyl xyloside & - & NT & NT & - \\
\hline Galactose & + & $\mathrm{w}$ & $\mathrm{w}$ & + \\
\hline Glucose & $+(\mathrm{D})$ & + & + & $+(\mathrm{D})$ \\
\hline Fructose & $+(\mathrm{D})$ & + & $\mathrm{w}$ & $+(\mathrm{D})$ \\
\hline Mannose & + (D) & + & $\mathrm{w}$ & $+(\mathrm{D})$ \\
\hline Sorbose & $-(\mathrm{L})$ & NT & NT & $-(\mathrm{L})$ \\
\hline Mannitol & + & + & - & + \\
\hline Methyl D-mannoside & - & NT & NT & - \\
\hline Methyl D-glucoside & - & NT & NT & $\mathrm{w}$ \\
\hline$N$-Acetylglucosamine & + & NT & NT & + \\
\hline Amygdalin & + & - & + & + \\
\hline Arbutin & + & NT & NT & + \\
\hline Aesculin & + & - & - & + \\
\hline Salicin & + & + & NT & + \\
\hline Cellobiose & + & + & w & $+(\mathrm{D})$ \\
\hline Maltose & + & + & $\mathrm{w}$ & + \\
\hline Lactose & $\mathrm{w}$ & - & - & - \\
\hline Melibiose & - & - & - & w \\
\hline Sucrose & + & + & w & + \\
\hline Trehalose & + & + & - & $+(\mathrm{D})$ \\
\hline Inulin & $\mathrm{w}$ & - & - & - \\
\hline Melezitose & - & - & - & $-(\mathrm{D})$ \\
\hline Raffinose & $-(\mathrm{D})$ & - & - & $\mathrm{w}(\mathrm{D})$ \\
\hline Xylitol & - & NT & NT & NT \\
\hline Gentibiose & + & NT & NT & NT \\
\hline Turanose & $-(\mathrm{D})$ & NT & NT & NT \\
\hline Lyxose & $-(\mathrm{D})$ & NT & NT & NT \\
\hline Tagatose & $-(\mathrm{D})$ & NT & NT & NT \\
\hline Fucose & $-(\mathrm{D}$ and $\mathrm{L})$ & NT & NT & NT \\
\hline Arabitol & $-(\mathrm{D}$ and $\mathrm{L})$ & NT & NT & NT \\
\hline Gluconate & - & NT & NT & NT \\
\hline 2-Keto gluconate & - & NT & NT & NT \\
\hline 5-Keto gluconate & - & NT & NT & NT \\
\hline \multicolumn{5}{|l|}{ Growth at $\left({ }^{\circ} \mathrm{C}\right)$ : } \\
\hline 0 & $+^{*}$ & + & + & - \\
\hline 30 & $+^{*}$ & - & - & + \\
\hline 35 & $-{ }^{*}$ & - & - & + \\
\hline 40 & $-^{*}$ & - & - & + \\
\hline
\end{tabular}


Table 1 (cont.)

\begin{tabular}{|lcccc|}
\hline Attribute & C. inhibens K1 & $\begin{array}{c}\text { C. funditum } \\
\text { DSM 5972 }\end{array}$ & $\begin{array}{c}\text { C. alterfunditum } \\
\text { DSM 5970 }^{\mathrm{T}}\end{array}$ & $\begin{array}{c}\text { C. piscicola } \\
\text { DSM 20730 }\end{array}$ \\
\hline Urease & - & $\mathrm{NT}$ & $\mathrm{NT}$ & - \\
$\mathrm{H}_{2}$ S production & - & $\mathrm{NT}$ & $\mathrm{NT}$ & - \\
Gelatin hydrolysis & - & - & - & NT \\
Gas from glucose & - & $\mathrm{NT}$ & $\mathrm{NT}$ & - \\
\hline
\end{tabular}

* Test performed in TSBS.

$\dagger$ Test performed in MMM.

$\ddagger$ Test performed on TSA.

$\S$ Test performed on HBA.

Table 2. Percentages $(w / w)$ of total fatty acids from $C$. inhibiens sp. nov. compared to data in the literature for a number of Carnobacterium species

\begin{tabular}{|c|c|c|c|c|c|c|c|c|c|c|c|c|}
\hline Bacterial species & $14: 0$ & $\begin{array}{l}16: 1 \\
\text { cis } 7\end{array}$ & $\begin{array}{l}16: 1 \\
\text { cis } 9\end{array}$ & $16: 1$ & $16: 0$ & $\begin{array}{c}18: 2 \\
\text { cis } 9,10\end{array}$ & $\begin{array}{c}18: 2 \\
\text { cis } 9,12\end{array}$ & $18: 1$ & $\begin{array}{l}18: 1 \\
\text { cis } 9\end{array}$ & $18: 0$ & $\begin{array}{l}\text { cyclo- } \\
19 \text { cis } 9\end{array}$ & $\begin{array}{l}20: 1 \\
\text { cis } 11\end{array}$ \\
\hline C. inhibens sp. nov. & $5 \cdot 4$ & & & $24 \cdot 2$ & $31 \cdot 1$ & & $10 \cdot 8^{*}$ & & $23 \cdot 4$ & $3 \cdot 5$ & & \\
\hline C. alterifunditum $\mathrm{pf} 1 \dagger$ & $5 \cdot 9$ & $21 \cdot 8$ & & & $33 \cdot 2$ & 0 & & & $18 \cdot 9$ & $4 \cdot 1$ & & $1 \cdot 6$ \\
\hline C. mobile MT37 & $2 \cdot 0$ & & $25 \cdot 5$ & $2 \cdot 5$ & $16 \cdot 0$ & & & $1 \cdot 5$ & 48.5 & $2 \cdot 5$ & & \\
\hline C. funditum $\mathrm{pf} 2 \div$ & $3 \cdot 1$ & $16 \cdot 5$ & & & $32 \cdot 2$ & $0 \cdot 7$ & & & $20 \cdot 7$ & $5 \cdot 0$ & & $0 \cdot 6$ \\
\hline C. divergens NCDO 2763 & $10 \cdot 5$ & & $11 \cdot 5$ & $1 \cdot 5$ & $20 \cdot 0$ & & & $2 \cdot 0$ & $28 \cdot 0$ & $4 \cdot 0$ & $19 \cdot 5$ & \\
\hline C. piscicola $\mathrm{NCDO} 2762 \ddagger$ & $10 \cdot 0$ & & $11 \cdot 0$ & $2 \cdot 0$ & $17 \cdot 5$ & & & $0 \cdot 5$ & $51 \cdot 5$ & $3 \cdot 5$ & & \\
\hline
\end{tabular}

* Could be 18:0 instead.

$\dagger$ Franzmann et al. (1991).

$\ddagger$ Collins et al. (1987).

chain saturated and monounsaturated types. The C18: 1 compound is a cis 9,12 isomer.

Members of the genus Carnobacterium have been isolated from a wide range of environments such as refrigerated meat products (Montel et al., 1991), salmonid fish (Hiu et al., 1984) and anoxic lake water in Antarctica (Schröder et al., 1980). They are difficult to distinguish from Lactobacillus sp. given the many characteristics representatives of these genera have in common. Both these bacterial groups are non-sporogenous Gram-positive rods that lack catalase and oxidase, and produce lactic acid during sugar fermentation. Carnobacteria are able to proliferate at low temperatures (psychrophily), but this is also a known feature for some Lactobacillus strains (Schröder et al., 1980). However, nearly all carnobacteria fail to grow on acetate containing media, while most lactobacilli do grow on such media. Moreover, carnobacteria are able to grow at a more alkaline $\mathrm{pH}$ than lactobacilli and some carnobacteria are motile while the lactobacilli are not. Another way to distinguish carnobacteria from lactobacilli is to compare the composition of the cellular fatty acids. Carnobacteria contain oleic acid as one of the major fatty acids (Collins et al., 1987) while lactobacilli do not. By comparing the $16 \mathrm{~S}$ rDNA sequences it has been concluded that the current species in the genus Carnobacterium are more closely related to the genus Vagococcus than to Lactobacillus (Wallbanks et al., 1990).

The $16 \mathrm{~S}$ rDNA sequence of strain $\mathrm{K}^{\mathrm{T}}$ strongly suggests it to be classified as a Carnobacterium species (Fig. 1) (this conclusion is in accordance with a previous sequence analysis, data not shown). Strain $\mathrm{K} 1^{\mathrm{T}}$ has some unique characteristics previously not described for members of the genus Carnobacterium. Firstly, it produces growth inhibitors in vitro (Jöborn et al., 1997) that suppress the growth of the bacterial fish pathogens Vibrio anguillarum and $A$. salmonicida, a property not found in the other Carnobacterium species tested (this study). Secondly, the fatty acid profile of strain $\mathrm{K} 1^{\mathrm{T}}$ does not correspond to any known profile within the genus Carnobacterium (Table 2). Finally, the phenotypic attributes of strain $K 1^{\mathrm{T}}$ (Table 1) differ from the characteristics of other Carnobacterium species.

A well-known bacterial fish pathogen Carnobacterium piscicola (Hiu et al., 1984) has previously been isolated from salmonid fish. The sequence analysis shows that C. piscicola and strain $\mathrm{K} 1^{\mathrm{T}}$ belong to different groups 


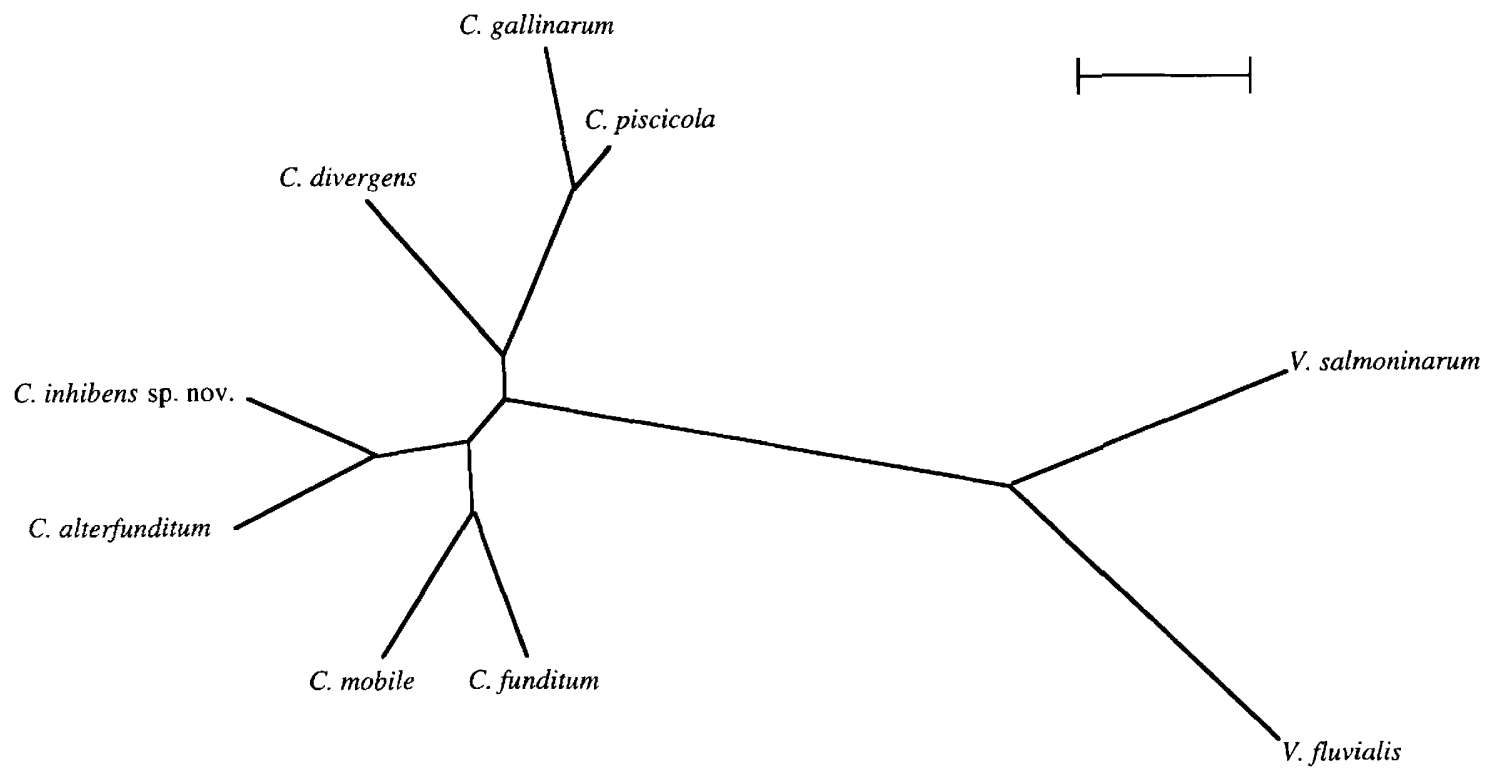

Fig. 1. Unrooted phylogenetic tree based on the comparison of the 165 rDNA sequence of the Carnobacterium inhibens sp. nov. with 16S rDNA sequences of C. alterfunditum (L08623), C. divergens (X54270), C. funditum (\$86170), C. gallinarum (X54269), C. mobile (X54271), C. piscicola (X54268), Vagococcus fluvialis (X54258) and Vagococcus salmoniarum (X54272). Bar, $1 \%$ sequence divergence.

within the genus Carnobacterium (Fig. 1). Moreover, strain $\mathrm{K}^{\mathrm{T}}$ differs from the $C$. piscicola (type strain) concerning utilization of seven carbon sources, the motility and the temperature range supporting growth (Table 1). Furthermore, strain $\mathrm{K} 1^{\mathrm{T}}$ was not able to cause disease in a previously performed infection study in Atlantic salmon (Jöborn et al., 1997), indicating it to be non-virulent.

There are three motile Carnobacterium species described (Collins et al., 1987; Franzmann et al., 1991; Spielmeyer et al., 1993). The phenotypic attributes of $C$. mobile, $C$. alterfunditum and $C$. funditum show many similarities with strain $\mathrm{K} 1^{\mathrm{T}}$ (see Table 1 ; Collins et al., 1987). They all form motile rods, and are heterofermentative, catalase-negative and oxidasenegative bacteria which grow at high salinities. The $16 \mathrm{~S}$ rDNA sequence similarity ranking shows that $C$. alterfunditum and strain $\mathrm{K} 1^{\mathrm{T}}$ form one group, and $C$. funditum and $C$. mobile cluster together in another group (Table 1). However, the sequence variation among the current species in the genus Carnobacterium is low (Wallbanks et al., 1990) making it hard to distinguish between species solely based on sequence analysis.

The biochemical analysis confirms that the motile Carnobacterium species differ from strain $\mathrm{K} 1^{\mathrm{T}}$. $C$. mobile diverges from strain $\mathrm{K} 1^{\mathrm{T}}$ concerning the utilization of at least five carbon sources, it grows at $35^{\circ} \mathrm{C}$ and the percentage of the fatty acid 18:1cis 9 is more than twice as high in C. mobile compared to strain $\mathrm{K} 1^{\mathrm{T}}$ (Collins et al., 1987). C. funditum and C. alterfunditum differ from strain $\mathrm{K} 1^{\mathrm{T}}$ regarding temperature sup- porting growth. Moreover, $C$. funditum differs from strain $\mathrm{K}^{\mathrm{T}}$ concerning its ability to utilize glycerol, arabinose, ribose, galactose, amygdalin, aesculin, lactose and inulin and $C$. alterfunditum concerning its ability to utilize glycerol, arabinose, ribose, galactose, fructose, mannose, mannitol, aesculin, cellobiose, maltose, lactose, melibiose, trehalose and inulin. Moreover, strain $\mathrm{K} 1^{\mathrm{T}}$ is able to hydrolyse hippurate, which is not the case for the other two Carnobacterium species.

The cellular fatty acid profiles for $C$. funditum and $C$. alterfunditum show similarities to strain $\mathrm{K} 1^{\mathrm{T}}$ in respect to all but two fatty acids. Strain $\mathrm{K} 1^{\mathrm{T}}$ contains $18: 2$ cis $9,12(10 \cdot 8 \%)$ which has not been identified in the other two strains (Table 2). It also contains 16:1 $(24.2 \%)$, but the exact identity of this fatty acid peak is not clarified. $C$. funditum and $C$. alterfunditum contain 16.5 and $21.8 \%$ of $16: 1$ cis 7 , respectively.

In summary, the ability of strain $\mathrm{K} 1^{\mathrm{T}}$ to inhibit the growth of Vibrio anguillarum and A. salmonicida seems to be a unique character among the carnobacteria. The closest known relative to strain $\mathrm{K} 1^{\mathrm{T}}$, based on sequence data, is $C$. alterfunditum. The genus Carnobacterium is a phylogenetically coherent group (Wallbanks et al., 1990) and the difference in 16S rDNA sequence between $C$. alterfunditum and strain $\mathrm{K} 1^{\mathrm{T}}$ is proposed to be sufficient to entitle a new species within the genus. The differences in fatty acid profiles and other phenotypic attributes support this conclusion. The name Carnobacterium inhibens is proposed for the new species. 


\section{Description of Carnobacterium inhibens sp. nov.}

Carnobacterium inhibens (in.hi'bens. M.L. adj. inhibens from L. v. inhibeo to inhibit, referring to the growthinhibitory activity that the bacterium shows).

Carnobacterium inhibens is a Gram-positive, motile (monotrichous), non-spore-forming rod which occurs singly or two, or as chains of four cells. Many standard laboratory media support growth but not MRS or TCBS. Colonies (TSA, $20^{\circ} \mathrm{C}$ ) are $1-2 \mathrm{~mm}$ in diameter, circular, entire, convex, and semi-translucent. The colour of the colonies is whitish at aerobic growth conditions and buff at anaerobic growth conditions. The temperature range that supports growth is $0-30{ }^{\circ} \mathrm{C}$ and the $\mathrm{pH}$ range that supports growth is 5.5-9.0. Does not produce catalase or oxidase but pseudo-catalase is produced on HBA. No gas is produced from glucose. Produces acid from sucrose, maltose, galactose, glucose, fructose, mannose, $\mathrm{N}$-acetylglucosamine, amygdalin, arbutin, aesculin, salicin, cellobiose, trehalose, lactose (weak), mannitol, ribose, inulin (weak), gentibiose and methyl $\beta$-D-glucopyranoside, whereas it does not produce acid from cyclo-dextrin, glycerol, erythritol, xylose, adonitol, methylxyloside, sorbose, rhamnose, dulcitole, inositol, tagatose, D-arabitol, L-arabinose, melezitose, melibiose, pullulan, glycogen, raffinose, methyl D-mannoside, methyl D-glucoside, starch, xylitol, turanose, lyxose, fucose, gluconate and sorbitol. Does not produce acetoin or $\mathrm{H}_{2} \mathrm{~S}$ and is not able to reduce nitrate to nitrite. Hydrolyses hippurate. $\beta$ glucosidase activity is demonstrated whereas no activity of the following enzymes have been detected: urease, $\beta$-galactosidase, $\beta$-glucuronidase, $\alpha$-galactosidase, arginine dihydrolase, alanyl-phenylalanyl-proline arylamidase, acid pyroglutamine arylamidase, $N$ acetyl- $\beta$-glucosaminidase. The most abundant cellular fatty acids are 16:0 (31.1\%), 16:1 (24.2\%) and $18: 1$ cis $9(23 \cdot 4 \%)$. Other fatty acids are $18: 2$ cis 9,12 or $18: 0(10.8 \%), 14: 0(5 \cdot 4 \%)$ and $18: 0(3.5 \%)$. Atlantic salmon (Salmo salar) is a host for $C$. inhibens. $C$. inhibens is not known to be related to disease. $C$. inhibens has a unique 16S rDNA signature and the significance of the branching points in the unrooted phylogenetic tree (Fig. 1) is $73 \%$ (C. funditum S86170/C. mobile X54271), 98.1\% (C. alterfunditum $\mathrm{L} 08623 / C$. inhibens strain $\left.\mathrm{K} 1^{\mathrm{T}}\right), 100 \%(C$. gallinarum X54269/C. piscicola X54268) and $100 \%$ (Vagococcus salmoninarum X54272/Vagococcus fluvialis X54258). The $C$. inhibens type strain $\left(\mathrm{K}^{\mathrm{T}}\right)$ has been deposited at CCUG as $31728^{\mathrm{T}}$. The EMBL accession number for the $16 \mathrm{~S}$ rDNA sequence is $\mathrm{Z} 73313$.

\section{ACKNOWLEDGEMENTS}

The authors would like to thank Drs T. Andlid, P. Conway and $\mathrm{J}$. Östling for valuable comments on the manuscript and Ms J. Ahrlinger for help with the preliminary 16S rRNA sequencing. This research was supported by grants from the Swedish Agricultural and Forestry Research Council, Swedish National Board for Industrial and Technical Development, and EWOS AB, Sweden.

\section{REFERENCES}

Axelsson, L. T. (1993). Lactic acid bacteria: classification and physiology. In Lactic Acid Bacteria, pp. 1-63. Edited by A. Salminen \& A. von Wright. New York: Marcel Dekker.

Baya, A. M., Toranzo, A. E., Lupiani, B., Li, T., Roberson, B. S. \& Hetrick, F. M. (1991). Biochemical and serological characterization of Carnobacterium spp. isolated from farmed and natural populations of striped bass and catfish. Appl Environ Microbiol 57, 3114-3120.

Brosius, G., Palmer, J. L., Kennedy, J. P. \& Noller, H. F. (1978). Complete nucleotide sequence of a $16 \mathrm{~S}$ ribosomal RNA gene from Escherichia coli. Proc Natl Sci USA 75, 4801-4805.

Collins, M. D., Farrow, J. A. E., Phillips, B. A., Ferusu, S. \& Jones, D. (1987). Classification of Lactobacillus divergens, Lactobacillus piscicola, and some catalase-negative, asporogenous, rodshaped bacteria from poultry in a new genus, Carnobacterium. Int J Syst Bacteriol 37, 310-316.

Dorsch, M. \& Stackebrandt, E. (1992). Some modifications in the procedure of direct sequencing of PCR amplified 16S rDNA. $J$ Microbiol Methods 16, 271-279.

Evelyn, T. P. T. \& McDermott, L. A. (1961). Bacteriological studies of fresh water fish. Can J Microbiol 7, 375-382.

Franzmann, P. D., Höpfl, P., Weiss, N. \& Tindall, B. J. (1991). Psychrophilic, lactic acid-producing bacteria from anoxic waters in Ace Lake, Antartica; Carnobacterium funditum sp. nov. and Carnobacterium alterfunditum sp. nov. Arch Microbiol 156, 255-262.

Heimbrook, M. E., Wang, W. L. L. \& Campbell, G. (1989). Staining bacterial flagella easily. J Clin Microbiol 27, 2612-2615.

Hiu, S. F., Holt, R. A., Sriranganathan, N., Seidler, R. J. \& Fryer, J. L. (1984). Lactobacillus piscicola, a new species from salmonid fish. Int J Syst Bacteriol 34, 393-400.

Humphrey, J. D., Lancaster, C. E., Gudkovs, N. \& Copland, J. W. (1987). The disease status of Australian salmonids: bacteria and bacterial diseases. J Fish Dis 10, 403-410

Jöborn, A., Olsson, C., Westerdahl, A., Conway, P. \& Kjelleberg, S. (1997). Colonisation in the fish intestinal tract and production of inhibitory substances in intestinal mucus and faecal extracts by Carnobacterium sp. strain K1. J Fish Dis 20, 383-392.

Knøchel, S. (1981). Occurence and some characteristics of Lactobacillus spp. isolated from fish. $J$ Appl Bacteriol 51, 10.

Kvasnikov, E. I., Kovalenko, N. K. \& Materinskaya, L. G. (1977). Lactic acid bacteria of freshwater fish. Mikrobiologiya 46, 619-624 (in Russian).

Leifson, E. (1963). Determination of carbohydrate metabolism of marine bacteria. J Bacteriol 85, 1183-1184.

Maniatis, T., Fritsch, E. F. \& Sambrook, J. (1982). Molecular Cloning : a Laboratory Manual. Cold Spring Harbor, NY : Cold Spring Harbor Laboratory.

Mårdén, P., Tunlid, A., Malmcrona-Friberg, K., Odham, G. \& Kjelleberg, S. (1985). Physiological and morphological changes during short term starvation of marine bacterial isolates. Arch Microbiol 142, 326-332.

Montel, M.-C., Talon, R., Fournaud, J. \& Champomier, M.-C. (1991). A simplified key for identifying homofermentative Lactobacillus and Carnobacterium spp. from meat. $J \mathrm{Appl}$ Bacteriol 70, 469-472.

Östling, J., Goodman, A. \& Kjelleberg, S. (1991). Behaviour of IncP-1 plasmids and a miniMu transposon in a marine Vibrio 
sp.: isolation of and starvation inducible lac operon fusions. FEMS Microbiol Ecol 86, 83-94.

Rainey, F. A., Dorsch, M., Morgan, H. W. \& Stackebrandt, E. (1992). 16S rDNA analysis of Spirochaeta thermophila: Its phylogenetic position and implication for the systematics of the order Spirochaetales. Syst Appl Microbiol 15, 197-202.

Ringø, E. (1993). Arctic charr, Salvelinus alpinus (L.), reared in fresh and sea water. $\mathrm{PhD}$ thesis, University of Tromsø.

Ross, A. J. \& Toth, R. J. (1974). Lactobacillus - a new fish pathogen. Prog Fish Cult 36, 191.

Saitou, N. \& Nei, M. (1987). The neighbor-joining method: a new method for reconstructing phylogenetic trees. Mol Biol Evol 4, 406-425.

Schröder, K., Clausen, E., Sandberg, A. M. \& Raa, J. (1980). Psychrophilic Lactobacillus plantarum from fish and its ability to produce antibiotic substances. In Advances in Fish Science and Technology, pp. 480-483. Edited by J. J. Connell. Farnham, Surrey: Fishing News Books.

Spielmeyer, W., McMeekin, T. A., Miller, J. \& Franzmann, P. D. (1993). Phylogeny of the Antarctic bacterium, Carnobacterium alterfunditum. Polar Biol 13, 501-503.

Strøm, E. (1988). Melkesyrebakterier i fisketarm. Isolasjon, karakterisering og egenskaper. Licentiate treatise. University of Tromsø.

Wallbanks, S., Martinez-Murcia, A. J., Fryer, J. L., Phillips, A. B. \& Collins, M. D. (1990). 16S rRNA sequence determination for members of the genus Carnobacterium and related Lactic acid bacteria and description of Vagococcus salmonarium sp. nov. Int $J$ Syst Bacteriol 40, 224-230.

Westerdahl, A., Olsson, J. C., Kjelleberg, S. \& Conway, P. L. (1991). Isolation and characterization of turbot (Scophthalmus maximus)-associated bacteria with inhibitory effect against Vibrio anguillarum. Appl Environ Microbiol 57, 2223-2228. 